\title{
Anti-Asian Hate Crime During the COVID-19 Pandemic: Exploring the Reproduction of Inequality
}

\author{
Angela R. Gover ${ }^{1} \cdot$ Shannon B. Harper ${ }^{2}$ (D) - Lynn Langton ${ }^{3}$ \\ Received: 10 May 2020 / Accepted: 11 June 2020 / \\ Published online: 7 July 2020 \\ (C) Southern Criminal Justice Association 2020
}

\begin{abstract}
Coronavirus Disease 2019 (COVID-19) is believed to have emerged in Wuhan, China in late December 2019 and began rapidly spreading around the globe throughout the spring months of 2020. As COVID-19 proliferated across the United States, Asian Americans reported a surge in racially motivated hate crimes involving physical violence and harassment. Throughout history, pandemic-related health crises have been associated with the stigmatization and "othering" of people of Asian descent. Asian Americans have experienced verbal and physical violence motivated by individuallevel racism and xenophobia from the time they arrived in America in the late 1700s up until the present day. At the institutional level, the state has often implicitly reinforced, encouraged, and perpetuated this violence through bigoted rhetoric and exclusionary policies. COVID-19 has enabled the spread of racism and created national insecurity, fear of foreigners, and general xenophobia, which may be related to the increase in antiAsian hate crimes during the pandemic. We examine how these crimes - situated in historically entrenched and intersecting individual-level and institutional-level racism and xenophobia - have operated to "other" Asian Americans and reproduce inequality.
\end{abstract}

Keywords Hate crime · COVID-19 · Coronavirus · Pandemic · Asian American · Asian

Angela R. Gover

Angela.gover@ucdenver.edu

Shannon B. Harper

sharper@iastate.edu

Lynn Langton

laustell@rti.org

1 School of Public Affairs, University of Colorado Denver, 1380 Lawrence Street, Suite 500, Denver, CO 80204, USA

2 Department of Sociology, Iowa State University, 510 Farm House Lane, Ames, IA 50011, USA

3 RTI International, 701 13th St NW, Suite 750, Washington, DC 20005, USA 


\section{Introduction}

"I have seen this incredible seesaw effect. We can go back to the turn of the century, when Chinese were the only people to be legally excluded from this country because people were so fearful of the jobs they were taking. That was seemingly a place that we would never go to anymore, that level of vitriol. We've seen it, though, in waves since then: World War II, we had an Asian enemy; Korean War, we had an Asian enemy; Vietnam War, we had an Asian enemy. And then we had Asian enemies that were economic in nature." Janet Yang (2020).

In the last week of 2019, the world began to take notice of reports out of Wuhan, China hospitals about an increase in pneumonia cases of unexplained origin (Wang, Horby, Hayden, \& Gao, 2020). Soon thereafter, scientists found that these illnesses were due to a new type of coronavirus (i.e., severe acute respiratory syndrome coronavirus 2 [SARS-CoV-2]), which causes a disease referred to as COVID-19 (i.e., 2019 coronavirus disease) (Centers for Disease Control and Prevention [CDC], 2020a). It is believed that the virus spread from animals to humans in Wuhan's open-air "wet markets" that sell fish and raw meat to consumers (CDC, 2020a), and by mid-January 2020 , began to spread rapidly throughout Asia and globally (Schumaker, 2020). By the end of January, the World Health Organization (WHO) declared a "Public Health Emergency of International Concern" (CDC, 2020b).

As all Americans grew accustomed to a "new normal" secluded lifestyle (e.g., social distancing requirements and stay-at-home orders) and mounting anxieties about the spread of COVID-19, Asian Americans (i.e., people of diverse ethnicities with origins in East Asia and Southeast Asia ${ }^{1}$ - have been additionally burdened by heightened racial tension and associated racist microaggressions and verbal attacks. Asian Americans have also reported a surge in a second epidemic targeting them specifically racially motivated hate crimes involving physical violence and harassment - despite the disease impacting people of all races/ethnicities (Chiu, 2020). Under the Hate Crime Statistic Act (28 U.S.C. § 534), hate crime is defined as "crimes that manifest evidence of prejudice based on race, gender and gender identity, religion, disability, sexual orientation, or ethnicity."

Hate crime may be used to "other" minority racial/ethnic groups who are perceived as dangerous (i.e., belief that people of Asian descent are solely responsible for causing and spreading COVID-19) and outside their place of belonging (Grove \& Zwi, 2006). Othering is embedded in racism (i.e., perceptions of white racial superiority) and xenophobia (i.e., fear of foreigners). Othering involves a process whereby the group at the top of the racial hierarchy (exemplified by whiteness in America) and/or individuals who believe that Asian Americans do not rightly belong in the U.S., seek to maintain the status quo by defining which members of society do and do not fully belong (Perry, 2001).

Asian Americans have experienced physical violence/hate crime and harassment (e.g., violent attacks during establishment of Chinatowns in the late 1800s [Chen, 2000]), persistent marginalizing stereotyping (e.g., the perpetuation of the "yellow

\footnotetext{
${ }^{1}$ People with origins in East Asia (Chinese, Japanese, Korean, Okinawan, Taiwanese, Tibetan) and Southeast Asia (Bruneian, Burmese, Cambodian, Filipino, Hmong, Indonesian, Laotian, Malaysian, Mien, Papua New Guinean, Singaporean, Timorese, Thai, Vietnamese).
} 
peril" myth at the turn of the $20^{\text {th }}$ century [Mudambi, 2019]), and verbal attacks and microaggressions motivated by individual-level racism and xenophobia from the time they arrived in America in the late 1700s up until the present day (Chen, 2000). At the institutional-level, the state (i.e., the federal and state governments) has often implicitly/ explicitly reinforced, encouraged, and perpetuated this violence through racist and xenophobic discriminatory rhetoric and exclusionary policies (e.g., Chinese Exclusion Act of 1881 [Yung, Chang, \& Lai, 2006]).

COVID-19 has enabled the spread of racism and created national insecurity, fear of foreigners, and general xenophobia, which may be associated with the increase in anti-Asian hate crime during the pandemic (Vachuska, 2020). Using the lens of othering theory, we examine how these crimes - situated in historically entrenched and intersecting individuallevel and institutional-level racism and xenophobia - have operated to other Asian Americans, thus reproducing inequality. A mix of media and empirical sources are used to critically explore this dynamic. This paper positions anti-Asian hate crime during the COVID-19 pandemic historically and in relation to racist and xenophobic othering. We expand scholarship through examining the pandemic-driven hate crime experiences of Asian Americans to more definitively define the concept of othering.

\section{Defining Hate Crime}

According to the Department of Justice (DOJ, n.d.), a hate crime involves a criminal act, including violent crime such as harassment, assault, murder, arson, vandalism, or threats to commit such crimes against a person or his/her property due to their real or perceived race, color, religion, nationality, country of origin, disability, gender or sexual orientation. Conversely, some incidents of bias and hate that occur against marginalized groups meet the legal definition of harassment, but are considered "hate incidents" or acts of prejudice that do not rise to the level of a criminal act (DOJ, n.d.). These are defined as "acts of prejudice that are not crimes [...] and do not involve violence, threats, or property damage" (DOJ, n.d., n.p.). This paper primarily focuses on anti-Asian hate crimes involving criminal physical violence or harassment; however, we also examine studies and media accounts of anti-Asian "hate incidents" that involve verbal violence or microaggressions and violent crime (i.e., hate incidents and hate crimes were not disaggregated).

Hate crime statutes vary widely across states and jurisdictions and are defined to include varying bias motivations that often carry penalty enhancements (DOJ, n.d.). Some states require the prosecutor to prove that bias was a "substantial factor" in the perpetrator's motivation for committing the crime against a person or persons of a protected category if the crime is to be considered a hate crime and receive penalty enhancements under state law (DOJ, n.d.). Conversely, under federal hate crime laws, bias can be an "incidental factor" in the commission of the crime (DOJ, n.d.).

\section{Othering Theory}

Othering is a concept found in the literature in reference to a dominant group marginalizing a non-dominant group in some way. Originating out of prejudice and fear, the 
act of othering involves a process that labels those thought to be different from oneself (Weis, 1995), wherein the racial group with the most power in American society (e.g., whites) or the group that believes they have "civic belonging" (i.e., believe they intrinsically belong in the U.S.) (Kim \& Sundstrom, 2014) stigmatize and distance individuals who are racially different (i.e., Asian Americans) (Grove \& Zwi, 2006; Kim $\&$ Sundstrom, 2014). Othering also serves to reinforce these dominant groups' notions of their own "normality," and position those who are different as deviant through a historical and ongoing process of marginalization, disempowerment, and social exclusion (Grove \& Zwi, 2006).

\section{Asian Americans and Historical Experiences of Othering}

In 2018, the estimated number of Asians in the United States was 22.2 million (U.S. Census Bureau, 2019), and they are projected to become the largest immigrant group in the U.S. by 2055 (Horowitz, Brown, \& Cox, 2019). Among all racial groups in the U.S., Asians are the fastest growing, increasing by $72 \%$ between 2000 and 2015 (Lopez, Ruiz, \& Patten, 2017). Recent studies show that as a bloc, voters from the Asian American community are wielding an influential voice in critical electoral battleground districts, and trends show that they have leaned increasingly Democratic in the past few elections (Zheng, 2019). The numbers of Asian American political candidates and elected officials have risen sharply as well (Zheng, 2019).

The following description of the early Asian immigrant experience seeks to place the othering of Asian Americans into a historical context, leading up to today's pandemicdriven experiences ranging from microaggressions and verbal harassment to assault and other violent hate crimes.

\section{Early Asian Immigrant Experience}

Established groups with civic belonging in the U.S. have long perceived new waves of immigrants with some degree of resentment (Fussell, 2014). Historically, all immigrant groups different from the existing white, English-speaking, Protestant American majority have endured high degrees of suspicion as they fought to gradually establish their place within American culture (Alba \& Foner, 2006). Unfortunately, in various forms, this nativist attitude (intricately tied to xenophobia) has reflected institutional racism, including restrictive federal immigration policies and legalized racial quotas and exclusions, some of which specifically targeted Asian immigrants (Kil, 2012). Additionally, violent racialized attacks on Asian communities by white majority groups throughout American history, especially during the $19^{\text {th }}$ and $20^{\text {th }}$ centuries, demonstrate the social entrenchment of this xenophobic mindset in the U.S. over time.

The California Gold Rush of the mid-1800s lured the first large group of Asian immigrants to the continental U.S.: Chinese entrepreneurs seeking to strike gold (Yung et al., 2006). Unfortunately, most did not achieve the overblown promises of profit (Yung et al., 2006). Unable to return to China and forced to compete for their livelihoods with white "forty-niners" (i.e., white migrants named for the year they began to arrive in California - 1849) from the eastern U.S., these laborers were cast as scapegoats for white migrants' employment frustrations due to their different looks, 
language, and customs (Yung et al., 2006). Forced to work for less than their white counterparts, Asian immigrants labored and lived under harsh conditions, toiling in dangerous mining operations and railroad construction (Yung et al., 2006). During this time, Chinese laborers faced institutional racism from the U.S. government in the form of undue tax burdens and legislative barriers to citizenship (Yung et al., 2006). Additionally, Chinese immigrants brought opium to the United States when they arrived to participate in the Gold Rush, and eventually established opium dens (i.e., places to buy, sell, and smoke opium) in Chinatowns throughout the West (Ahrens, 2013). Many Americans eventually became addicted to the drug, which resulted in a national drug panic (Ahrens, 2013). Collectively, these historical events and injustices culminated in the Chinese Exclusion Act of 1882, the first legal decree banning an entire ethnic group from immigration and eligibility for U.S. citizenship (Kil, 2012). The Act was primarily fueled by racist and xenophobic fears among white workingclass laborers about depressed wages, and fanned by a proliferation of "Chinese invasion" rhetoric in the media. Such language is just one example of the "hordes of immigrant invaders" trope long-used throughout U.S. history to support varying political agendas (Zimmer, 2019).

The Chinese American communities of the late 1800s responded to housing segregation policies by forming Chinatowns in major U.S. urban centers where they constructed governing bodies to maintain community order (Chen, 2000). Instead of facing severe, racially-motivated maltreatment in mines or factories, many Chinese workers chose self-employment through restaurants, retail establishments, and laundries (Chen, 2000). Unfortunately, several of these communities faced a rash of violent, deadly attacks perpetrated by the white majority, sometimes escalating to residents being run out of town with their homes burned to the ground (Chen, 2000).

The early 1890s saw a new influx of immigrants from Asian countries, primarily out of Japan, to work in agriculture as well as logging, fishing, mining, and service professions (Aoki, 2010). White resentment and calls for Japanese exclusion laws soon followed resulting in "The Gentleman's Agreement" of 1908 between the U.S. and Japan, whereby Japan agreed to stop further labor immigration to the U.S. (Aoki, 2010). However, thousands of wives, parents, and children of current Japanese residents were allowed to immigrate; and in the face of U.S. racial segregation, Japanese families came together to establish enclaves along the West coast (Aoki, 2010; Lee, 2002). Like the Chinese before them, Japanese and Korean newcomers faced legislative barriers to land ownership, citizenship, and education inspired by racism, which concluded with a 1924 amendment to the Chinese Exclusion Act that denied citizens from any Asian nation to immigrate to the U.S. These anti-Asian laws remained in place until 1943 (Lee, 2002).

After Japanese victories in the Sino-Japanese and Russo-Japanese Wars at the turn of the $20^{\text {th }}$ century, a new "yellow peril" stereotype arose in the U.S typecasting Asians of all ethnicities, domestic and foreign, as threatening agents bent on world domination (Mudambi, 2019). This pernicious stereotype othered Asian Americans as bloodthirsty, sneaky foreigners who were not to be trusted in the same way as Americans of other ancestries. The yellow peril myth perfectly and troublingly set the stage for the next chapter in the American government's discriminatory treatment of Asian communities as the U.S. entered World War II (Lyman, 2000). 


\section{Japanese Concentration Camps}

In what remains one of the most shameful violations of constitutional rights in U.S. history, President Franklin D. Roosevelt signed an executive order allowing for the forced removal of the entire Japanese population of the U.S. West coast (the majority of whom were American citizens) two months after the Japanese attack on Pearl Harbor in December of 1941 (Conrat \& Conrat, 1972). Allowed only to bring what they could carry, over 120,000 persons of Japanese ancestry were herded into concentration camps surrounded by barbed wire and guarded by armed military personnel, where they remained through the duration of the war (Howard, 2009). Anyone with $1 / 16^{\text {th }}$ or more Japanese blood was eligible for removal, perceived as a potential threat (Burton, Farrell, Lord, \& Lord, 2011).

Ironically, due to xenophobic paranoia and fear of Japanese American sabotage, the U.S. military at Hickham Base in Honolulu, HI had parked their airplanes in a contained area to be more easily guarded, making the planes "sitting-ducks" for air attacks by Japanese bombers (Miller, 1992). Despite the wide-ranging feelings of distrust by the larger society towards Asian Americans at that time, tens of thousands of Asian American soldiers of varying ethnicities enlisted and served with valor during the war (Parks, 2004).

With the passage of the Immigration Act in 1965 which struck down race as a barrier for immigration, Asian immigrants flowed into the U.S. once again (Yung et al., 2006). New waves of East Asian immigrants arrived in the U.S. through the mid to late twentieth century (Chin, 1996). As these new groups of Americans integrated into U.S society, a new stereotype proliferated: the myth of the "model minority" (Chou \& Feagin, 2015). The model minority stereotype promotes the notion that Asian Americans are a monolithic group who have enjoyed great success in American society due to a cultural emphasis on a strong work ethic, natural-born intelligence, and through stressing the importance of education and achievement within their families (Chou \& Feagin, 2015). Such a seemingly affirmative representation of an entire race masks a negative dynamic of consistently relegating Asian Americans to a permanent foreigner status (i.e., othering) when compared to other Americans (Chou \& Feagin, 2015). Additionally, this myth works to confirm the belief that America does not have any racial discrimination problems, suggesting that all racial groups operate on an equal playing field with the hardest working groups inevitably rising to the top of their own accord, share equal privilege, and do not experience obstacles brought on by others' racist attitudes and behavior (Chou \& Feagin, 2015). Finally, in some respects, this myth fosters suspicion and resentment towards Asian communities and immigrants as a whole (McGowan \& Lindgren, 2006).

\section{Stigmatization and Pandemics}

The devastating impact of infectious disease has loomed large throughout human history causing more fatalities than any other medical cause (Pappas, Kiriaze, Giannakis, \& Falagas, 2009). Unfortunately, eruptions of xenophobia have historically followed close on the heels of pandemics. Especially when viral outbreaks are deadly, fear often drives those at risk to place blame on some "other," or some group external to their own national, religious, or ethnic identity (Muzzatti, 2005). Sickness cultivates 
fear, which in turn cultivates bias (Muzzatti, 2005). Consequently, minority groups have often found themselves erroneously blamed for spreading germs, as insiders perceived them to be "dirty" or "sickly" (Taylor, 2019). As a nation built by waves of new immigrants, newcomers to the U.S. have traditionally borne the brunt of corresponding waves of othering in the form of ignorance and blame for a myriad of societal maladies, most notably those concerning infectious disease; a few examples include Irish Catholic immigrants held responsible for "Irish disease" (cholera), Jewish immigrants blamed for "consumption" (tuberculosis), Irish and German newcomers blamed for yellow fever (McKiven, 2007), and Italian immigrants blamed for polio (Cohn, 2012).

The COVID-19 pandemic is not the first time a public health crisis has resulted in the othering and disparate treatment of Asian Americans. When the bubonic plague began in San Francisco, CA in 1900, public health officials implemented a race-based response by quarantining Chinese residents in Chinatown, the epicenter of the outbreak, while allowing white merchants to leave (Barde, 2004). More recently, East Asians across the globe experienced stigmatization during the SARS outbreak of 20022004 (Eichelberger, 2007).

Despite comprising a tapestry of diverse ethnicities, Asian Americans have been historically viewed as a monolith, othered by the myth of the model minority in times of peace and economic security, while othered as a scapegoat in times of economic adversity, wars, or pandemics.

\section{Anti-Asian Hate Crime during the COVID-19 Pandemic}

Prior sections have explored how anti-Asian racism and xenophobia in the U.S. have been reproduced and historically entrenched at the individual- and institutional-levels during times of crisis and significant change so as to other Asian Americans and reinforce their inequality. The sections below examine how hate crime exacted in response to the COVID-19 pandemic is an extreme and exacerbated replication of this othering process; and how institutional-level racist and xenophobic rhetoric targeting Asian Americans has established the structure through which individual-level hate crimes occur.

\section{What's in a Name?}

The WHO (2015) followed their "Best Practices for the Naming of New Human Diseases" in selecting "COVID-19" as the name for the disease caused by SARSCoV-2. These best practices endeavor to avoid offending any cultural, social, national, regional, professional, and/or ethnic groups (WHO, 2015). According to Dr. Keiji Fukuda, the WHO Assistant Director-General for Health Security, disease names can create significant consequences in terms of backlash against affected religious or ethnic groups (WHO, 2015). WHO (2015) best practices also advocate the avoidance of geographic locations or references to culture, population, or language that incites fear.

Disregarding the WHO's (2015) official nomenclature, President Donald Trump publicly used the terms "Chinese virus" or "China virus" for COVID-19 in various tweets between March 16-18, 2020 (Fallows, 2020), as well as in a White House press 
conference on March 19 ${ }^{\text {th }}$, and then repetitively defended his use of the terms throughout March and early April (Chiu, 2020). A widely circulated image captured at the March $19^{\text {th }}$ press conference shows the president's notes with the "corona" in "coronavirus" crossed out and replaced with "Chinese" (Smith, 2020). When confronted about his use of the "Chinese" descriptive rather than the WHO-official "COVID-19" term, the president responded, "It's from China. That's why. It comes from China. I want to be accurate" (Fallows, 2020). While President Trump repeatedly referred to COVID-19 as the "Chinese virus" or "China virus," Secretary of State Mike Pompeo preferred the term "Wuhan virus" (Rogers, 2020). Additionally, an unnamed White House staffer allegedly used the term "kung flu" (Boyer, 2020).

Some argue that such terminology is both racist and xenophobic (Chiu, 2020) as it promotes anti-Asian bias and exclusion (Little, 2020), which may increase the risk of hate crime (Cabanatuan, 2020). The president's early rhetoric undoubtedly did not serve to protect the Asian community. Before Trump made these remarks in midMarch, racist acts and harassment targeting Asian Americans had already surged; they continued to increase through March and April following his statements (Haynes, 2020). On the coattails of President Trump's remarks, other political officials have also used derogatory language to blame the Chinese for causing COVID-19. For example, Senator John Cornyn (R-TX) said in a press conference on March $18^{\text {th }}$ that China was to "blame" for the spread of COVID-19 because they are a "culture where people eat bats and snakes and dogs and things like that" (Wu, 2020). On March $23^{\text {rd }}$, the Department of Homeland Security (DHS) issued a warning that white supremacists may use the crisis to justify harm or violence against Asian Americans (Mallin \& Margolin, 220). Also in late March, the Federal Bureau of Investigation (FBI) anticipated that there would be a surge in anti-Asian hate crime during the pandemic and therefore alerted law enforcement agencies to be on heightened alert for bias-motivated incidents (Mallin \& Margolin, 2020).

According to a recent not yet published news content analysis (detailed in the San Francisco Chronicle) conducted by Professor Russell Jeung of the Asian American Studies department at San Francisco State University, the number of "hate incidents" reported in the media increased in response to the xenophobic language used by public officials (Cabanatuan, 2020; Jeung, 2020). Moreover, Dr. Jeung remarked that the timing in the sharp rise in hate incidents specifically coincided with the president's use of the term, "Chinese virus" (Jeung, 2020; Kang, 2020). He argued that his findings demonstrate that political language can provoke racial hatred and associated violence (Sheyner, 2020). At the same time, it appears that the study defines "hate incidents" as involving aggregated hate crimes and hate incidents, making it difficult to distinguish between the two.

Similarly, in the week following the president's March $19^{\text {th }}$ press conference, the "Stop AAPI Hate" (AAPI refers to Asian American and Pacific Islander) website that includes an anti-AAPI harassment, discrimination, and violent attacks self-reporting tool, recorded 673 "racist incidents" (Cabanatuan, 2020); however, it is not known how many of these incidents apply directly to the Asian community. Similar to Dr. Jeung's (2020) study, "racist incidents" likely involve the aggregate of hate crimes and hate incidents.

Additionally, in a pre-print manuscript, Vachuska (2020) analyzed Google Trends data and found that attitudes toward minority racial groups have been affected by the 
COVID-19 pandemic. Specifically, to measure anti-Chinese sentiment, the author examined the proportion of and relationships among searches for a specific racial epithet used to describe a person of Chinese descent, coronavirus searches, Chinese restaurants, etc. (Vachuska, 2020). The author reported strong evidence of a relationship between COVID-19 and an increase in anti-Chinese sentiment, including discriminatory treatment towards the Asian community and Chinese restaurants (Vachuska, 2020). More research is needed to clarify anti-Asian hate crime trends during and following the COVID-19 pandemic.

As awareness grew about the growing number of hate incidents and hate crimes against Asian Americans, accusations of racism and xenophobia around the president's insistence on using the term, "Chinese virus," exploded in the media. The White House responded to the uproar by accusing the media of manufacturing "fake outrage" over nothing, citing previous epidemics named after geographic locations: Spanish flu, West Nile, zika virus, and ebola (Mangan, 2020). However, the WHO (2015) appropriately named the novel coronavirus "COVID-19" to avoid a connection with a geographic area and therefore circumvent the stigmatization of people living in that area or of similar ancestry worldwide. The correlating increase in hate crimes against Asian Americans during the COVID-19 pandemic (Jeung, 2020; Vachuska, 2020) underlines the importance of avoiding geography in the naming of communicable diseases (Little, 2020). ${ }^{2}$

On March 23, 2020, President Trump walked back his use of the term "Chinese virus," noting in a network news interview that the American people were already well aware of the virus' true origins; however, he declined to apologize for using the geographic descriptor (Leigh, 2020). Additionally, the president declared that Asian Americans should not be blamed "in any way, shape, or form" for COVID-19 (Samuels, 2020). He also denounced the recent spate of pandemic-related racial attacks on Asian Americans (Samuels, 2020). Unfortunately, for many hate crime victim advocates and Asian Americans, this change of heart came too late; too much damage had already occurred (Shyong, 2020). One could argue that in the critical early days when the language coming from America's leadership set the tone, concerns about its effects on Asian Americans had been negligent at best, and destructive at worst.

\section{Hate Crime Data}

The Hate Crime Statistics Act of 1990 requires the federal government to collect data about crimes motivated by race, religion, sexual orientation, or ethnicity (FBI, n.d.). The nation's largest sources of crime data, the FBI's Uniform Crime Report (UCR) and the Bureau of Justice Statistics' (BJS) National Crime Victimization Survey (NCVS), provide national estimates of hate crime (Masucci \& Langton, 2017). Both sources define hate crime according to the federal definition noted in the Introduction. Hate crime data are also collected by advocacy organizations that provide assistance to marginalized communities (e.g., Southern Policy Law Center, Asian Pacific Policy Planning Council, Anti-Defamation League) (Gladfelter, Lantz, \& Ruback, 2017;

\footnotetext{
${ }^{2}$ Additionally, it is important to note that hate crimes against Asian Americans may have increased following national awareness of COVID-19 regardless of the president's problematic rhetoric.
} 
Jenness \& Grattet, 2001). Each of these data sources have significant limitations (Gladfelter et al., 2017).

UCR and NCVS data have been utilized in the present study because they are the largest and most representative of the population. We examined hate crime data from the two collections for the 16-year period from 2003 to 2018, the years of data available for both sources. ${ }^{3}$ Both collections provide data on annual counts of racially-motivated hate crime. The UCR enables these counts to be disaggregated by the specific type of racial bias motivating the offense (e.g., anti-Asian bias; anti-African American bias; anti-Hispanic violence, etc.), while the NCVS statistics can be disaggregated by the race of the victim. The sections below describe the two collections and what they tell us about anti-Asian hate crime prior to COVID-19. Throughout these data sections, we refer to anti-Asian hate crime; however, both the UCR and NCVS numbers include hate crimes against Pacific Islanders and Native Hawaiians as well.

Because the NCVS is based on a sample, it is necessary to aggregate several years of data to have sufficient sample sizes for reliable estimates of anti-Asian hate crime. UCR hate crime counts were calculated from Hate Crime Statistics Program data available on the FBI (2003-2007, 2014-2018) website, and NCVS estimates were generated from the public-use data files available through the National Archive of Criminal Justice Data (n.d.) (BJS, 1992-2018).

\section{UCR}

The FBI annually collects summary crime data from thousands of city, county, college and university, state, tribal, and federal law enforcement agencies nationwide through the UCR Program. Through a supplementary collection to the UCR, the Hate Crime Statistics Program, the FBI additionally collects data on hate crime incidents, offenses, and victims, including details about the offender's bias motivation and whether he or she was motivated by anti-Asian bias. Although the UCR hate crime statistics can be used to identify victims of anti-Asian bias, it should be noted that the bias motivation is based on the offender's perceptions of the victim. In other words, the victim may not necessarily be of Asian descent, but if the offender believed they were and targeted them for that reason, the incident would be counted as an anti-Asian hate crime. The FBI data also distinguish between single-bias hate crime incidents, and multiple-bias incidents in which the offender(s) was motivated by two or more biases. The discussion below examines single-bias hate crimes, which account for the majority of UCR hate crimes (about 98\% in 2018), as we are interested in hate crimes motivated by antiAsian bias alone. It is also important to note that both the UCR and NCVS include hate crime data involving Asian Americans and documented and undocumented Asian immigrants (Addington, 2008).

UCR data reveal that during the 5-year period from 2003 to 2007, there was an average of 9314 victims of single-bias hate crimes. Of those victims, $67.0 \%,(n=6241)$

\footnotetext{
3 The NCVS hate crime data are available in public-use files beginning in 2003. For both collections, the most recent year of data available is 2018. Both data collections operate on a calendar year (January-December). Once the collections close on December 31 st, the BJS and FBI spend several months cleaning and processing the annual files and typically release the data several months later in the summer or fall. In other words, 2019 data are expected to be released in the late summer or early fall of 2020.
} 
were motivated by racial/ethnic/ancestral bias. Among these 6241 racially motivated hate crimes, $4.1 \%(n=254)$ were motivated by anti-Asian bias. In comparison, during the most recent 5-year period from 2014 to 2018, there was an average of 7690 singlebias hate crime victims, of which $59.6 \%(n=4581)$ were targeted due to racial/ethnic/ ancestral bias, and anti-Asian bias accounted for 3.8\% $(n=176)$ of these crimes. Across these two 5-year periods, there was a $26.6 \%$ decrease in single-bias racially motivated hate crimes, and a $30.8 \%$ decrease in anti-Asian motivated hate crime.

When interpreting UCR hate crime statistics it is important to take into account the underreporting problems associated with these data. In 2018, for example, at least 80 cities in the U.S. with populations over 100,000 people reported zero hate crimes for the year. Underreporting may occur at the agency-level because reporting to the FBI is voluntary. Within agencies, underreporting may occur due to the difficulty law enforcement officers have identifying objective evidence of the bias motivation to determine whether or not the incident is a hate crime (Gladfelter et al., 2017). A victim must identify the crime as motivated by prejudice in order for law enforcement to classify it as a hate crime; and when detectives investigate, they must collect evidence to prove that the incident was motivated by bias, which is often challenging and unclear (Gladfelter et al., 2017). In regard to the latter however, the determination, about whether to charge the offense as a hate crime often falls on the prosecutor, not the police. In addition, UCR data may undercount hate crime if victims do not report to police because they do not believe the racially motivated violence was a crime, have language and cultural barriers, lack trust in the government and police, have a fear of retaliatory violence, and/or believe that they will not be taken seriously by criminal justice system actors (Davis \& O’Neill, n.d.).

\section{NCVS}

The NCVS has been used to collect hate crime data since 2003 (Masucci \& Langton, 2017). Unlike the UCR that includes offenses known to and reported by police departments, the NCVS collects information from a nationally representative sample of households about experiences with crime both reported and not reported to police (i.e., the "dark figure of crime"). Upon identifying that a respondent has experienced crime, the NCVS asks victims if they have any reason to believe that the victimization was a "hate crime or crime of prejudice or bigotry" (NCVS, 2016 [question 161]). Victimizations are only categorized hate crimes if the victim can provide certain types of evidence to support an affirmative response (Addington, 2008). Additionally, the NCVS asks hate crime victims about the types of bias they suspected motivated the crime (Masucci \& Langton 2017).

NCVS data reveal that from 2003 to 2007, there was an average of 265,062 annual hate crime victimizations, of which $67.1 \%(n=177,946)$ were motivated by racial/ ethnic bias. About $2.5 \%$ of hate crime victimizations were against persons identifying as Asian, Pacific Islander or Native Hawaiian $(n=6625)$, and the vast majority $(>99 \%)^{4}$ were motivated by anti-racial/ethnic bias. During the more recent 2014 2018 period, there was an average of 224,435 total hate crimes with $57.7 \%(n=$

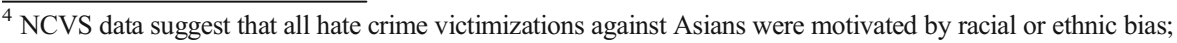
however, the data are based on a sample so this is not a true $100 \%$.
} 
$128,474)$ motivated by racial/ethnic bias. About $2.7 \%$ of the hate crime victimizations were against Asians, Pacific Islanders, or Native Hawaiians $(n=6158)$, again with the vast majority (94\%) motivated by the offender's racial or ethnic bias. Across the two periods, it appears that hate crime overall declined by $15.3 \%$, and hate crimes against people of Asian descent declined by $7.0 \%$; however, the differences between the estimates are not statistically significant when the confidence intervals are taken into account. Importantly, the NCVS data also reveal that less than half of hate crime victimizations overall $(43.2 \%)$ are reported to police, and this is true among Asian victims as well $(47.6 \%)$.

\section{Reconciling Variations in Estimates}

The UCR reported a large percentage decrease $(30.8 \%)$ in anti-Asian motivated hate crime while the NCVS indicated a small percentage decrease (7.0\%) across the two 5year time periods. Discrepancies in percentages suggest vast underreporting of hate crime to police and magnify the hidden nature of hate crime against Asian Americans in the U.S. today. Indeed, NCVS hate crime data reveal that $47.6 \%$ of Asian victims do not report to the police. While both results reflect a decrease in hate crimes motivated by anti-Asian bias across time, the large differences between the two statistics make it unclear how extensive the decrease is. After the COVID-19 pandemic has subsided, scholars should compare old and new UCR and NCVS hate crime data to determine whether the prevalence of anti-Asian hate crime has markedly increased/changed. ${ }^{5}$ Inconsistencies in both sources' anti-Asian hate crime data collectively show the limitations of using official data to accurately estimate the prevalence of hate crime.

Additionally, the vast difference between the UCR's and NCVS's reported numbers of racially motivated hate crimes is striking and problematic. For example, from 2003 to 2007 , UCR data indicate that there were 6241 hate crimes motivated by racial/ethnic prejudice, while NCVS data demonstrate that 177,946 hate crimes involved racial/ ethnic bias motivation, which is an approximate $186 \%$ difference between the two. Discrepancies between the two data collections make it difficult to determine the actual pervasiveness of racially motivated hate crime in the U.S. across time. NCVS data is arguably more reliable than UCR data because it includes both reported and unreported hate crimes. With this in mind, NCVS data suggest that anti-Asian hate crime has remained an alarming problem across time, while UCR data imply the opposite (or a less alarming persistent trend).

\section{Assessing 2020 Hate Crime Data}

Data from the 2020 NCVS and UCR Hate Crime Statistics Program are expected to be released in late 2021. At that point, researchers will be able to assess both the extent to which law enforcement data show a spike in anti-Asian hate crimes known to police

\footnotetext{
${ }^{5}$ It is important to note that when thinking about comparing any kind of percent declines, the FBI treats their numbers as a complete enumeration, when in reality, there is agency- and item-level missingness among the data. The FBI does not produce standard errors so it is difficult to determine whether an apparent change in a number is actually within the margin of error.
} 
and whether there were changes in the numbers of Asian victims of hate crimes reported or not reported to police. Although the two data sources may not be consistent in terms of the magnitude of any spike, together they should provide empirical evidence about whether the qualitative, anecdotal suggestions of a pandemic-related increase in anti-Asian hate crimes was true nationwide. Together the two sources will show whether there were overall increases in the number of hate crimes against Asian Americans and whether the victims were comfortable seeking help from the police.

\section{Personal Experiences of Hate Crime During the COVID-19 Pandemic}

Social media has played a significant role in publicizing racialized attacks against Asian Americans during the COVID-19 pandemic. Tweets have exposed instances of antiAsian hate crime involving physical violence and harassment, mainly after bystander videos were posted and picked up by the broader media. Twitter hashtags such as \#WashTheHate and \#HateIsAVirus trended on social media platforms as users responded to the incidents they viewed on their screens (Elder, 2020). For example, New York City police urged the victim of a COVID-19 hate crime to come forward and make a report after a video surfaced on February $5^{\text {th }}$ of a man physically and verbally assaulting her while she was wearing a facemask in a Chinatown subway station, calling her a "diseased (expletive)" (Sosa \& Brown, 2020).

In another incident on March $10^{\text {th }}$, a Korean American woman in midtown Manhattan was grabbed by the hair, shoved, and punched in the face by an assailant (Miles, 2020). The perpetrator yelled at the victim, "You've got coronavirus, you Asian (expletive)" and "Where's your (expletive) mask?" (Miles, 2020). The victim suffered a dislocated jaw (Miles, 2020).

One of the most horrific examples of COVID-19-related hate crimes occurred on March $14^{\text {th }}$ at a Sam's Club in Midland, TX, when a perpetrator attacked a family from Myanmar, stabbing three victims including a 2-year-old girl and a 6-year-old boy (Aziz, 2020). The assailant told police he feared the victims were Chinese and infecting others with the coronavirus (Aziz, 2020). Another extreme example occurred on April $5^{\text {th }}$, when an Asian American woman in Brooklyn was doused with acid by a man who snuck up behind her as she was taking her trash outside her front door, causing second degree burns to her body, face, and hands (Moore \& Cassady, 2020).

In late March, a 26-year-old Asian American man in a Brooklyn subway explained how a man spat in his face, and when he asked the man why he did so, the perpetrator yelled at him, "You (expletive) Chinese spreading the coronavirus!" (Moore \& Bensimon, 2020) The perpetrator then unzipped his jacket and pointed to a weapon saying, "You wanna do this?" (Moore \& Bensimon, 2020).

\section{Psychological Effects of Hate Crimes}

Many scientific studies have established a correlation between racialized victimization and poor mental health outcomes (e.g., Gee, Spencer, Chen, Yip, \& Takeuchi, 2007). Since the emergence of COVID-19, there has been a $22 \%$ total increase in people accessing the Mental Health America anxiety screening tool; among users, the increase in Asian American respondents has been 39\% (Campbell \& Ellerbeck, 2020). Research also suggests that hate crime victims experience more severe consequences compared to 
victims of non-hate crimes (Mellgren, Andersson, \& Ivert, 2017). Specifically, McDevitt, Balboni, Garcia, and Gu (2001) reported that bias crimes impact victims differently than non-bias crimes in that victims of bias crimes are more fearful and experience intrusive thoughts following their victimization.

\section{Institutional-Level Response}

\section{Federal Response}

In the last week of March 2020, Congresswoman Grace Menge (D-NY) introduced a resolution calling for all public officials to condemn anti-Asian discrimination (Jeung, Kulkarni, \& Choi, 2020). Additionally, the resolution called for federal law enforcement agencies to address pandemic-related hate crimes through data collection, documentation, and investigation (Jeung et al., 2020). Finally, Menge called for states to set up multi-agency task forces to address COVID-19-related racial bias concerning safe retail access, fair employment, and quality mental health services in educational settings for Asian American students and others affected by the pandemic (Jeung et al., 2020).

While many in the Asian community appreciated Trump's March $23^{\text {rd }}$ reversal regarding his use of the term "Chinese virus" and the positive comments he made about Asian Americans, advocates continue to await a meaningful response from the federal government, such as the creation of a DOJ Task Force to address hate crimes against the Asian community (Warner, 2020). As Matt Nguyen-Ngo, Civil Rights Fellow at the nonprofit OCA-Asian Pacific American Advocates expressed, "Trump did say Asian Americans are not to blame, but he hasn't done anything beyond that [...] It's been a very lackluster response" (Chapman, 2020; Kang, 2020). At a March $26^{\text {th }}$ White House press briefing on the pandemic, when asked what he is doing to stop anti-Asian hate crimes in the country, Trump replied, "I don't know" (Chapman, 2020).

In addition to the lack of response from the Oval Office, neither the DOJ nor the CDC have done much to respond to the pandemic. In the past, the CDC has responded quickly to prevent racialized violence, as it did during the 2003 SARS outbreak (far less prevalent or deadly than COVID-19), and the DOJ acted quickly after the 2001 terror attacks (Campbell \& Ellerbeck, 2020). Lamenting the lack of action, a group of 12 U.S. senators penned a letter to the U.S. Commission on Civil Rights requesting official guidance on federal response: "There has not been a concerted effort from federal agencies to prevent and address anti-Asian sentiment related to the COVID-19 pandemic" (Campbell \& Ellerbeck, 2020). In response, Assistant Attorney General, Eric Dreiband stated that hate crimes would be prosecuted to the full extent of the law (Campbell \& Ellerbeck, 2020).

\section{State Response}

On February 13, 2020, in response to the recent uptick in verbal attacks and other racial incidents targeting Asian Americans in Los Angeles, CA, county officials held a news conference denouncing racist incidents against the Asian community related to fears 
around COVID-19 (Capatides, 2020). Officials urged the public not to buy into stereotypes and misinformation about Asians, specifically citing two separate bullying incidents in public schools that resulted in the hospitalization of school-aged victims (City News Service, 2020). In a more concrete response to the increase in harassment and physical assault directed at Asian Americans due to COVID-19, New York's Attorney General, Letitia James established a state hotline for reporting hate incidents and hate crimes (New York Attorney General, 2020).

\section{Discussion/Conclusion: Anti-Asian Hate Crime and the Reproduction of Inequality}

Despite a long history in North America and increasing numbers and political influence today, Asian American communities have continued to experience a recurring dynamic of othering. Racism and xenophobia woven into the social fabric may generate harmful individual-level attitudes and actions against Asian Americans that other and exclude them from national belonging. Racially dominant and/or well-established groups in America that hold social power have historically resented the arrival and presence of less well-established and influential groups such as Asian Americans, perceiving them as "foreigners" outside of their "proper" place of belonging and a threat to notions of community and sovereignty (Grove \& Zwi, 2006; Kim \& Sundstrom, 2014). Such nativist and xenophobic resentments intricately overlap with racism, wherein those in power fear and resist those who look different, speak dissimilar languages, and have unique cultural practices in comparison. As a result, the othering of Asian Americans has been historically repetitive in the form of bigoted exclusionary practices and violence, thus serving to entrench their foreigner and marginalized status and maintain the racial and nationalist hierarchy.

One could argue that the social and institutional entrenchment of racism and xenophobia has resulted in the repetitive re-emergence of anti-Asian stereotypes across time. For example, the prevalent discrimination and bigotry wrought by the yellow peril and the model minority myths further marked and established Asian Americans as inherently different from the majority population (McGowan \& Lindgren, 2006). Additionally, institutionalized processes and government policies (elevated tax burdens, education and housing segregation, land ownership restrictions, and barriers to Asian immigration and citizenship [Zimmer, 2019]), further sustained the othering of Asian Americans.

This othering process is amplified and replicated during pandemics when widespread fear of catching disease engenders prejudice against groups that are different from the majority population, positioning them as effective scapegoats (Muzzatti, 2005; Taylor, 2019). Ostracizing Asian Americans in this way metaphorically builds a wall between those socially perceived as most important (i.e., whites) and those perceived as less important (i.e., Asian Americans), creating a boundary where "never the two shall meet." This othering dynamic has reemerged during the COVID-19 pandemic, as illustrated by President Trump's and other political officials' use of racially derogatory language (Fallows, 2020; Rogers, 2020; Wu, 2020).

As cognitive linguists Lakoff and Johnson (2003) have long established, metaphors are ubiquitous in forming our world view. The adjective "Chinese" in "Chinese virus" 
is particularly problematic as it associates the infection with an ethnicity. Connecting group identities with explicitly medical language serves to categorize those group identities as other. Historically, this connection has influenced anti-immigrant rhetoric and policy in the United States. The WHO's (2015) best-practices in naming infectious diseases exemplifies the importance of severing this connection in order to avoid stigma against geographic locations and ethnic groups.

Though most public officials eventually reversed course in their "China virus" rhetoric, regardless of whether this reversal was motivated by a sudden altruistic understanding or by political calculation, the damage had already been done. At any rate, any commitment to avoiding the public othering of Asian Americans was short-lived. As late as April 17, 2020, President Trump put out a tweet criticizing House Speaker Nancy Pelosi for making a February trip to San Francisco's Chinatown in support of Asian American owned businesses, after declaring in another tweet that he had already "closed the BORDER TO CHINA" (capitalized letters used by the president) (Behrmann, 2020). This seeming failure to distinguish between the residents of San Francisco's Chinatown and foreign nationals from the nation of China reinforces the idea of their enduring foreignness. Additionally, through the late spring of 2020, political focus increasingly turned to placing blame for the COVID-19 pandemic on the nation of China; a by-product of this focus is increased suspicion and fear in the American consciousness towards Asian Americans, creating the perfect climate to cultivate further hate crime (Jeung et al., 2020).

One could argue that the historical perpetuation of this othering process, embedded in fear of perceived outsiders and racial hatred, has allowed for more extreme, violent, and devastating violence and state abuse, such as the Japanese Concentration Camps following the Pearl Harbor attacks (Conrat \& Conrat, 1972), and the seeming influx of hate crime we see today with the COVID-19 pandemic. Hate crimes during the COVID-19 pandemic are an extreme manifestation of othering illustrating the replicative and cumulative effects of the historical embeddedness of racism and xenophobia. That is, perpetrators exact violence to dehumanize and ostracize Asian Americans, stigmatizing and "marking" them as deviant to destroy their sense of belonging (Kim \& Sundstrom, 2014), encourage and perpetuate ongoing exclusion, sustain feelings of superiority, and restore feelings of normalcy and comfort. It is likely that this rash of COVID-19 related hate crimes and incidents will have enduring deleterious psychological, emotional, and physical effects on Asian American victims and Asian communities, exacerbated by decades of generational trauma (Comas-Díaz, 2016). Arguably equally as devastating is the damage to society of normalizing the othering of any minority group based on race, ethnicity, religion, national origin, disability, gender identity, and/or sexual orientation. Although immigration status was not specifically explored in this paper, it is important to note that Asian immigrants without citizenship status may experience exacerbated devastating health effects of COVID-19 hate crime as they have reduced access to resources that may help to address that harm due to fears of deportation upon reporting (Dorn et al., 2011).

COVID-19 is a public health matter, not a racial one (Jeung et al., 2020). Not only is it critical to stop the spread of COVID-19, but also the racial hatred it has produced (Jeung et al., 2020). It is also essential that we take the lessons learned from racialized fear derived from historical events and apply that knowledge to feelings of fear and anxiety during the pandemic (Jeung et al., 2020). Unfortunately, the pandemic-related stigmatization of Asian Americans and Asians across the globe may continue long after 
the cessation of COVID-19. Americans must confront incidents of discrimination headon: in schools, workplaces, businesses, and public spaces, in addition to demanding a robust response from law enforcement and the federal and state governments when hate crimes occur (Jeung et al., 2020).

In summary, across time, socially entrenched racism and xenophobia toward Asian Americans have repetitively recurred through individual-level prejudiced attitudes and actions. Moreover, these attitudes and actions have been reinforced by institutional-level support during times of crisis or great change, including the coronavirus pandemic. As a result, racial/ethnic inequality has been reproduced through the establishment of an " $u s$. vs. them" modus operandi that relegates Asian Americans to the bottom of the social hierarchy, wrongly and maliciously marking them unworthy of the same rights and treatment as those at the top. Such othering has led to a climate in which Asian Americans are more vulnerable to racialized forms of aggression, including hate crimes.

\section{References}

Alba, R., \& Foner, N. (2006, October 1). The second generation from the last great wave of immigration: Setting the record straight. Migration Policy Institute. Retrieved from https://www.migrationpolicy. org/article/second-generation-last-great-wave-immigration-setting-record-straight.

Addington, L. (2008). Current issues in victimization research and the NCVS's ability to study them. Bureau of Justice Statistics. Retrieved from https:/www.bjs.gov/content/pub/pdf/Addington.pdf.

Ahrens, D. (2013). Drug panics in the twenty-first century: Ecstasy, prescription drugs, and the reframing of the war on drugs. Albany Government Law Review, 6, 397-436.

Aoki, K. (2010). The yellow Pacific: Transnational identities, diasporic racialization, and myth(s) of the Asian century. UC Davis Law Review, 44, 897-951.

Aziz, S. (2020, April 12). Anti-Asian racism must be stopped before it is normalised. Al Jazeera. Retrieved from https://www.aljazeera.com/indepth/opinion/anti-asian-racism-stopped-normalised200412103717485.html. Accessed 23 Apr 2020.

Barde, R. (2004). Plague in San Francisco: An essay review. Journal of the History of Medicine and Allied Sciences, 59(3), 463-470.

Behrmann, S. (2020, April 16). Chinatown is not part of China': Trump's tweet at Pelosi is met with criticism online. USA Today. Retrieved from https://www.usatoday.com/story/news/politics/2020/04/16/trumpschinatown-tweet-pelosis-visit-draws-criticism-online/5149296002/. Accessed 23 Apr 2020.

Boyer, D. (2020, March 18). Trump spars with reporter over accusation that staffer called coronavirus 'Kung flu.' The Washington Times. Retrieved from https://www.washingtontimes.com/news/2020/mar/18 /trump-spars-reporter-over-accusation-staffer-calle/. Accessed 1 Apr 2020.

Bureau of Justice Statistics (1992-2018). National Crime Victimization Survey, Concatenated File, [United States], 1992-2018. Inter-university Consortium for Political and Social Research [distributor], 2020-03-05.

Burton, J., Farrell, M., Lord, F., \& Lord, R. (2011). Confinement and ethnicity: An overview of world war II Japanese American relocation sites. Seattle, WA: University of Washington Press.

Cabanatuan, M. (2020). Coronavirus: Asian American groups compile hate crime reports as trump persists in 'Chinese virus' attacks. San Francisco Chronicle. Retrieved from https://www.sfchronicle. com/bayarea/article/Coronavirus-Asian-American-groups-compile-hate-15144295.php. Accessed 5 Apr 2020.

Campbell, A. F. C., \& Ellerbeck, A. (2020, April 16). Federal agencies are doing little about the rise in antiAsian hate crime. San Francisco Chronicle. Retrieved from https://www.nbcnews.com/news/asianamerica/federal-agencies-are-doing-little-about-rise-anti-asian-hate-n1184766. Accessed 30 Apr 2020.

Capatides, C. (2020, February 14). Bullies attack Asian American teen at school, accusing him of having coronavirus. CBS News. Retrieved from https://www.cbsnews.com/news/coronavirus-bullies-attackasian-teen-los-angeles-accusing-him-of-having-coronavirus/. Accessed 18 Mar 2020. 
Centers for Disease Control and Prevention. (2020a). Coronavirus disease 2019 (Covid-19) situation summary. Retrieved from https:/www.cdc.gov/coronavirus/2019-ncov/cases-updates/summary.html.

Centers for Disease Control and Prevention. (2020b). New ICD-10-CM code for the 2019 novel coronavirus (COVID-19), April 1, 2020. Retrieved from https://www.cdc.gov/nchs/data/icd/Announcement-NewICD-code-for-coronavirus-3-18-2020.pdf.

Chapman, M. (2020, March 26). Trump flops after being asked what he's doing to protect Asian-Americans from hate crimes: 'I don't know.' Raw Story. Retrieved from https:/www.rawstory.com/2020/03/trumpflops-after-being-asked-what-hes-doing-to-protect-asian-americans-from-hate-crimes-i-dont-know/. Accessed 10 Apr 2020.

Chen, T. (2000). Hate violence as border patrol: An Asian American theory of hate violence. Asian Law Journal, 7, 69-102.

Chin, G. J. (1996). The civil rights revolution comes to immigration law: A new look at the immigration and nationality act of 1965. National Carolina Law Review, 75, 273-284.

Chiu, A. (2020, March 20). Trump has no qualms about calling the coronavirus the 'Chinese Virus.' That's a dangerous attitude, experts say. The Washington Post. Retrieved from https:/www.washingtonpost. com/nation/2020/03/20/coronavirus-trump-chinese-virus/. Accessed 4 Apr 2020.

Chou, R. S., \& Feagin, J. R. (2015). The myth of the model minority: Asian Americans facing racism. New York: Paradigm Publishers.

City News Service (2020, February 13). L.A. officials fear anti-Asian racism amid coronavirus worries. Los Angeles Daily News. Retrieved from https://www.dailynews.com/2020/02/13/1-a-officials-fear-anti-asianracism-amid-coronavirus-worries/. Accessed 14 Mar 2020.

Cohn, S. K. (2012). Pandemics: Waves of disease, waves of hate from the plague of Athens to AIDS. Historical Research, 85(230), 535-555.

Comas-Díaz, L. (2016). Racial trauma recovery: A race-informed therapeutic approach to racial wounds. In A. N. Alvarez, C. T. H. Liang, \& H. A. Neville (Eds.), Cultural, Racial, and Ethnic Psychology Book Series. The Cost of Racism for People of Color: Contextualizing Experiences of Discrimination (pp. 249-272). American Psychological Association.

Conrat, M., \& Conrat, R. (1972). Executive order 9066: The internment of 110,000 Japanese Americans. Scrimshaw Press: Online publisher.

Davis, R. L., \& O’Neill, P. (n.d.). The hate crimes reporting gap: Low numbers keep tensions high. In The IACP police chief Retrieved from https://www.policechiefmagazine.org/the-hate-crimes/. Accessed 27 Apr 2020.

Department of Justice (n.d.). Learn about hate crimes. Retrieved from https://www.justice. gov/hatecrimes/learn-about-hate-crimes.

Dorn, T., Ceelen, M., Tang, M., Browne, J. L., de Keijzer, K., Buster, M., \& Kees, D. (2011). Health care seeking among detained undocumented migrants: A cross-sectional study. BMC Public Health, 11, 190-200.

Eichelberger, L. (2007). SARS and New York's Chinatown: The politics of risk and blame during an epidemic of fear. Social Science \& Medicine, 65(6), 1284-1295.

Fallows, J. (2020, March 18). A reporter's notebook. A 2020 time capsule. The Atlantic. Retrieved from https://www.theatlantic.com/notes/2020/03/2020-time-capsule-5-the-chinese-virus/608260/. Accessed 1 Apr 2020.

Federal Bureau of Investigation. (n.d.). Hate crime statistics. Retrieved from https://www.fbi. gov/services/cjis/ucr/hate-crime.

Fussell, E. (2014). Warmth of the welcome: Attitudes toward immigrants and immigration policy in the United States. Annual Review of Sociology, 40, 479-498.

Gee, G. C., Spencer, M., Chen, J., Yip, T., \& Takeuchi, D. T. (2007). The association between self-reported racial discrimination and 12-month DSM-IV mental disorders among Asian Americans nationwide. Social Science \& Medicine, 64(10), 1984-1996.

Gladfelter, A. S., Lantz, B., \& Ruback, R. B. (2017). The complexity of hate crime and bias activity: Variation across contexts and types of bias. Justice Quarterly, 34(1), 55-83.

Grove, N. J., \& Zwi, A. B. (2006). Our health and theirs: Forced migration, othering, and public health. Social Science \& Medicine, 62(8), 1931-1942.

Haynes, S. (2020). As coronavirus spreads, so does xenophobia and anti-Asian racism. Time. Retrieved from https://time.com/5797836/coronavirus-racism-stereotypes-attacks/. Accessed 11 Apr 2020. 
Horowitz, J. M., Brown, A., \& Cox, K. (2019, April 9). Race in America 2019. Pew Research Center. Retrieved from https://www.pewsocialtrends.org/2019/04/09/race-in-america-2019/. Accessed 17 Apr 2020.

Howard, J. (2009). Concentration camps on the homefront: Japanese Americans in the house of Jim Crow. Chicago, IL: University of Chicago Press.

Jenness, V., \& Grattet, R. (2001). Making hate a crime: From social movement to law enforcement. New York: Russell Sage Foundation.

Jeung, R. (2020, April 3). Incidents of coronavirus discrimination march 26-April 1, 2020: A report for A3PCON and CAA. Asian Pacific Policy and Planning Council. Retrieved from http://www. asianpacificpolicyandplanningcouncil.org/wp-content/uploads/Stop_AAPI_Hate_Weekly_ Report4_3_20.pdf.

Jeung, R., Kulkarni, M. P., \& Choi, C. (2020, April 1). Epidemic of hate: Asian xenophobia amid coronavirus. Los Angeles Times. Retrieved from https://www.latimes.com/opinion/story/2020-04-01/coronavirus-antiasian-discrimination-threats. Accessed 20 Apr 2020.

Kang, E. (2020, March 31). Asian Americans feel the bite of prejudice during the COVID-19 pandemic. NPR WBEZ Chicago. Retrieved from https://www.npr.org/local/309/2020/03/31/824397216/asian-americansfeel-the-bite-of-prejudice-during-the-c-o-v-i-d-19-pandemic.

Kil, S. H. (2012). Fearing yellow, imagining white: Media analysis of the Chinese exclusion act of 1882. Social Identities, 18(6), 663-677.

Kim, D. H., \& Sundstrom, R. R. (2014). Xenophobia and racism. Critical Philosophy of Race, 2(1), $20-44$.

Lakoff, G., \& Johnson, M. (2003). Metaphors we live by. Chicago, IL: University of Chicago Press.

Lee, E. (2002). The Chinese exclusion example: Race, immigration, and American gatekeeping, 1882-1924. Journal of American Ethnic History, 21(3), 36-62.

Leigh, K. (2020, March 25). Trump says he'll stop using the term 'Chinese virus.' Bloomberg. Retrieved from https://www.bloomberg.com/news/articles/2020-03-25/trump-says-he-ll-stop-using-chinese-virus-easingblame-game. Accessed 4 May 2020.

Little, B. (2020, March 20). Trump's 'Chinese' virus is part of a long history of blaming other countries for disease. Time. Retrieved from https://time.com/5807376/virus-name-foreign-history/. Accessed 1 May 2020.

Lopez, G., Ruiz, N. G., \& Patten, E. (2017, September 8). Key facts about Asian Americans, a diverse and growing population. Pew Research Center. Retrieved from https:/www.pewresearch.org/fact-tank/2017 /09/08/key-facts-about-asian-americans/.

Lyman, S. (2000). The "yellow peril" mystique: Origins and vicissitudes of a racist discourse. International Journal of Politics, Culture, and Society, 13(4), 683-747.

Mallin, A., \& Margolin, J. (2020, March 24). Homeland security warns terrorists may exploit COVID-19 pandemic. $A B C$ News. Retrieved from https://abcnews.go.com/Politics/homeland-security-warnsterrorists-exploit-covid-19-pandemic/story?id=69770582. Accessed 8 Apr 2020.

Mangan, D. (2020, March 18). Trump defends calling coronavirus 'Chinese virus' - 'it's not racist at all.' CNBC. Retrieved from https:/www.cnbc.com/2020/03/18/coronavirus-criticism-trump-defends-sayingchinese-virus.html. Accessed 12 Apr 2020.

Masucci, M., \& Langton, L. (June, 2017). Hate crime victimization, 2004-2015. Bureau of Justice Statistics. Retrieved from https://www.bjs.gov/content/pub/pdf/hcv0415.pdf.

McDevitt, J., Balboni, J., Garcia, L., \& Gu, J. (2001). Consequences for victims: A comparison of bias-and non-bias-motivated assaults. American Behavioral Scientist, 45(4), 697-713.

McGowan, M. O., \& Lindgren, J. (2006). Testing the 'model minority' myth. Northwestern University Law Review, 100(1), 331-377.

McKiven, H. M. (2007). The political construction of a natural disaster: The yellow fever epidemic of 1853. The Journal of American History, 94(3), 734-742.

Mellgren, C., Andersson, M., \& Ivert, A. K. (2017). For whom does hate crime hurt more? Journal of Interpersonal Violence. A comparison of consequences of victimization across motives and crime types Epub ahead of print.

Miles, D. (2020, March 11). 'Where's your (expletive) mask?': Asian woman attacked in Manhattan hate crime. ABC News7. Retrieved from https://abc7ny.com/6003396/. Accessed 23 Mar 2020.

Miller, E. S. (1992). Target: Pearl Harbor by Michael Slackman (book review). The Journal of Military History, 56(3), 528-535. 
Moore, T., \& Bensimon, O. (2020,March 25). Asian man spat on in latest coronavirus hate crime in Brooklyn station. New York Post. Retrieved from https://nypost.com/2020/03/25/asian-man-spat-on-in-latestcoronavirus-hate-crime-in-brooklyn-station/. Accessed 18 Apr 2020.

Moore, T., \& Cassady, D. (2020, April 6). Brooklyn woman burned outside home in possible acid attack. New York Post. Retrieved from https://nypost.com/2020/04/06/brooklyn-woman-burned-outside-home-inpossible-acid-attack/. Accessed 29 Apr 2020.

Mudambi, A. (2019). South Asian American discourses: Engaging the yellow peril-model minority dialectic. Howard Journal of Communications, 30(3), 284-298.

Muzzatti, S. L. (2005). Bits of falling sky and global pandemics: Moral panic and severe acute respiratory syndrome (SARS). Illness, Crisis \& Loss, 13(2), 117-128.

National Archive of Criminal Justice Data. (n.d.). UCR and NCVS hate crime data. Retrieved from https://www.icpsr.umich.edu/icpsrweb/content/NACJD/index.html.

National Crime Victimization Survey. (2016). National Crime Victimization Survey: NCVS-2 crime incident report. Retrieved from https://www.bjs.gov/content/pub/pdf/ncvs18_cir.pdf.

New York Attorney General. (2020, March 23). AG James launches hotline to combat coronavirus hate crimes and xenophobic rhetoric. Retrieved from https://ag.ny.gov/press-release/2020/ag-james-launcheshotline-combat-coronavirus-hate-crimes-and-xenophobic-rhetoric. Accessed 11 Apr 2020.

Pappas, G., Kiriaze, I. I., Giannakis, P., \& Falagas, M. E. (2009). Psychosocial consequences of infectious diseases. Clinical Microbiology and Infection, 15(8), 743-747.

Parks, K. R. (2004). Revisiting Manzanar: A history of Japanese American internment camps as presented in selected federal government documents 1941-2002. Journal of Government Information, 30(5-6), 575-593.

Perry, B. (2001). In the name of hate: Understanding hate crime. London: Routledge.

Rogers, K. (2020, March 10). Politicians' use of 'Wuhan virus' starts a debate health experts wanted to avoid. The New York Times. Retrieved from https://www.nytimes.com/2020/03/10/us/politics/wuhan-virus.html. Accessed 27 Mar 2020.

Samuels, B. (2020). Trump expresses support for Asian Americans after repeatedly using term 'Chinese virus'. The Hill. Retrieved from https://thehill.com/homenews/administration/489107-trump-expresses-supportfor-asian-americans-after-repeatedly-using. Accessed 24 Apr 2020.

Schumaker, E. (2020, April 23). Timeline: How coronavirus got started. ABC News. Retrieved from https://abcnews.go.com/Health/timeline-coronavirus-started/story?id=69435165. Acceessed 6 May 2020.

Sheyner, G. (2020, April 8). Supervisors denounce xenophobia as Asian American groups report more harassment. Mountain View Voice. Retrieved from https://mv-voice.com/news/2020/04/08/supervisorsdenounce-xenophobia-as-asian-american-groups-report-more-harassment. Accessed 15 Apr 2020.

Shyong, F. (2020, March 23). Column: 'It's just too much': Asian Americans confront xenophobia, economic devastation and the coronavirus. Los Angeles Times. Retrieved from https://www.latimes. com/california/story/2020-03-23/coronavirus-devastation-immigrants. Accessed 19 Apr 2020.

Smith, A. (2020, March 19). Photo of Trump remarks shows 'corona' crossed out and replaced with 'Chinese' virus. NBC News. Retrieved from https:/www.nbcnews.com/politics/donald-trump/photo-trumpremarks-shows-corona-crossed-out-replaced-chinese-virus-n1164111. Accessed 26 Apr 2020.

Sosa, A., \& Brown, L. (2020, February 5). Woman wearing face mask attacked in possible coronavirus hate crime. New York Post. Retrieved from https://nypost.com/2020/02/05/woman-wearing-face-maskattacked-in-possible-coronavirus-hate-crime/. Accessed 27 Feb 2020.

Taylor, S. (2019). The psychology of pandemics: Preparing for the next global outbreak of infectious disease. Cambridge, England: Cambridge Scholars Publishing.

U.S. Census Bureau. (2019, May 8). Asian-American and Pacific Islander Heritage Month: May, 2019. Retrieved from https://www.census.gov/newsroom/facts-for-features/2019/asian-american-pacificislander.html.

Vachuska, K. F. (2020). Initial effects of the coronavirus pandemic on racial prejudice in the United States: Evidence from Google trends. https://doi.org/10.31235/osf.io/bgpk3.

Wang, C., Horby, P. W., Hayden, F. G., \& Gao, G. F. (2020). A novel coronavirus outbreak of global health concern. Lancet, 392(10223), 470-473 Retrieved from https://www.thelancet. com/journals/lancet/article/PIIS0140-6736(20)30185-9/fulltext.

Warner, M. (2020, May 4). Warner requests DOJ plan to address coronavirus-related anti-Asian discrimination, hate crimes. Press Release. Retrieved from https:/www.warner.senate.gov/public/index.cfm/2020 /5/warner-requests-doj-plan-to-address-coronavirus-related-anti-asian-discrimination-hate-crimes. Accessed 6 May 2020. 
Weis, L. (1995). Identity formation and the process of 'othering': Unravelling sexual threads. Educational Foundations, 9, 17-33.

World Health Organization. (2015, May 8). WHO issues best practices for naming new human infectious diseases. Retrieved from https:/www.who.int/mediacentre/news/notes/2015/naming-new-diseases/en/

Wu, N. (2020, March 18). USA Today: GOP senator says China 'to blame' for coronavirus spread because of 'culture where people eat bats and snakes and dogs'. USA Today. Retrieved from https://www.usatoday. com/story/news/politics/2020/03/18/coronavirus-sen-john-cornyn-says-chinese-eating-bats-spreadvirus/2869342001/. Accessed 16 Apr 2020.

Yang, J. (2020, April 17). The power and pain of being Asian American during the coronavirus crisis. Sheer Intelligence Podcast. Retrieved from https://www.kcrw.com/culture/shows/scheer-intelligence/powerpain-being-asian-american-coronavirus. Accessed 29 Apr 2020.

Yung, J., Chang, G., \& Lai, H. (Eds.). (2006). Chinese American voices: From the gold rush to the present. Berkeley, CA: University of California Press.

Zheng, B. Q. (2019 April 9). The patterns of Asian American's partisan choice: Policy preferences and racial consciousness. Social Science Quarterly, 100(5), 1593-1608.

Zimmer, B. (2019, August 6). Where does Trump's 'invasion' rhetoric come from? The Atlantic. Retrieved from https:/www.theatlantic.com/entertainment/archive/2019/08/trump-immigrant-invasion-languageorigins/595579/. Accessed 10 Apr 2020.

Publisher's Note Springer Nature remains neutral with regard to jurisdictional claims in published maps and institutional affiliations.

\begin{abstract}
Angela R. Gover, Ph.D., has been a Professor of Criminology and Criminal Justice at the University of Colorado School of Public Affairs since 2006. Dr. Gover received her Ph.D. in Criminology and Criminal Justice from the University of Maryland. Dr. Gover's published work appears in over 100 journal articles and edited volumes (i.e., book chapters) such as Child Abuse \& Neglect, Violence and Victims, Journal of Interpersonal Violence, Journal of Child Sexual Abuse, and Violence Against Women. Dr. Gover remains active in her profession by serving on editorial boards for several journals in her field. Her current research focuses on the criminal justice system's response to intimate partner violence, specifically, domestic violence offender treatment, personal protection orders, and law enforcement officer attitudes towards domestic violence.
\end{abstract}

Shannon B. Harper, Ph.D., is an Assistant Professor of criminal justice in the Sociology Department and U.S. Latino/a Studies Program at Iowa State University. Dr. Harper's research explores the relationship between intimate partner violence and intimate partner homicide (IPH) and the gendered contexts through which both occur. She examines the neighborhood social and structural factors that influence IPH, as well as how the criminal justice system and community resources operate to address it and the abuse that precipitates it. Dr. Harper's work also investigates how race/ethnicity, class, and gender intersect to shape marginalized survivors' interpersonal victimization experiences, specifically Latina and African American women. Her published works can be found in multiple peer-reviewed journals and edited volumes.

Lynn Langton, Ph.D., is a Senior Research Criminologist at RTI International. Her research focuses on victimization, victim services, sexual violence, hate crime, financial fraud and white-collar crime, policecommunity relations, and survey methodology. Prior to joining RTI in 2018, Dr. Langton served as Victimization Unit Chief for the Bureau of Justice Statistics where she directed numerous large-scale national projects, including the National Crime Victimization Survey. 